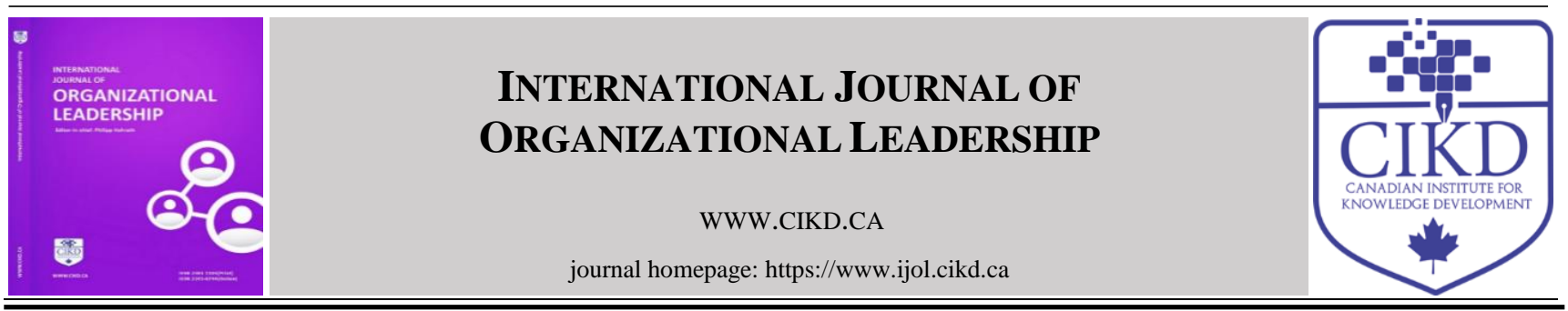

\title{
Leadership Styles of Principals in Private Higher Secondary Schools in Nepal
}

\author{
Rishi Prasad Tiwari \\ Principal, Pinnacle College, Lalitpur, Nepal
}

\begin{abstract}
Keywords:

Leadership style, Democratic

leadership, Autocratic

leadership, Laissez-faire

leadership

\section{Received}

12 April 2021

Received in revised form

18 April 2021

Accepted

18 April 2021

*Correspondence:

tiwaririshi716@gmail.com

This article focuses on principals' leadership style in private schools in Nepal regarding their job experience, age factors, level of education, and gender issues. It is based on the three dimensions of the leadership of Principals. They are democratic, autocratic, and laissez-faire, and they were examined with the rating style questionnaires as perceived by principals themselves and their teachers. The population sample of this study covered 78 principals and 163 teachers of different private higher secondary schools. The data for the qualitative study were collected, and Stata programming was applied as a statistical tool. The findings of this research indicated that most respondents, including principals themselves with different demographic characters, gave a high score for the democratic leadership styles of the principals. Basically, no variation was noted between the leadership style of male and female principals. But, respondents of academically highly qualified female teachers and more experienced teachers gave high scores for autocratic and laissez-faire leadership style in relation to few management functions like decision making, goal setting, and communication only. Conclusively, the democratic leadership style of principals was highly desirable, but autocratic leadership style and laissez-faire leadership styles were deemed desirable.
\end{abstract}

Quality leadership is a key element to develop the entire academia and society. An excellent educational leader is in utter need of the $21^{\text {st }}$ century to cope and compete with the global academic network. Sungtong (2007) found three main characteristics of principle's leadership in dealing with educational and cultural reform: increasing participation, transferring vision and producing changes, and recognizing foundation. The effectiveness of leaders in academic sectors is always valued by their abilities to contribute to improving the quality of education and providing harmony in school culture. Pont, Nushe, and Moorman (2008) claim that effective school leaders improve the efficiency and equity of schooling. It has been a universal principle that the success of any educational organization (school) depends on the leadership styles they practice as a principal.

This article investigates principals' leadership styles in private higher secondary schools in Nepal 
concerning their job experience, age factors, and level of education and gender issues. Both male and female principals of different demographic characters like young to old age group, less experienced to more experienced, the master degree to $\mathrm{PhD}$ scholars are leading various schools as principals. The principals' leadership styles in private schools of Nepal have been raised a debatable matter. According to the gender issue in leadership, Mathema (2006) says male managers differ significantly from their female counterparts. In contrast, women follow participative and interactive approaches, but men depend less on such approaches. The principal's abilities and skills are central to building a school society that promotes meaningful teaching and learning activities. There are various groups of people in a school system, such as faculty, non-teaching, support staff, and students. And they are from different culture and social backgrounds, and various ethnic communities; of course, they have different desires, abilities, and attitudes. So, it is challenging for the principal to organize them into a common set of school structures that provide full satisfaction to all of them to achieve the institutional goal. According to Robbins and Judge (2007), a good leadership style can perform the critical task in managing human resources materials and financial activities into productivity in the most effective way. Therefore, principals' leadership styles are the main factors to strengthen the quality of teachinglearning and the overall performance of the school society. Sapkota (2008) has undertaken his research study on leadership in a public school in Nepal, but no research works have been done about the leadership of private higher secondary schools. So, it is noticed that the research on leadership practices of principals in private higher secondary schools in Nepal is insufficient. No researchers have stated which one is the dominant type of leadership practice in Nepal's existing private higher secondary school. Do their demographic variables determine the leadership styles of principals? And which leadership styles would be considered the best fit for Nepal's private higher secondary schools? The key concern of this research work is to quest for the dominant type of leadership styles of principals and whether the leadership types of principals are influenced or not by their demographic variables. It is also believed that democratic, autocratic, and Laissez-faire leadership styles have prevailed in private higher secondary schools in Nepal. In this context the main objective of the study is to examine the extent of prevalence of various leadership styles of principals or directors in private higher secondary schools in Nepal and their different demographic characteristics.

\section{Literature Review}

\section{Leadership style}

Leadership is the way of a leader leading an organization to achieve institutional goals. A principal is regarded as the leader in a school. Academic achievements depend upon the leadership role and performance of a principal. So, leadership is a consistent pattern of behavior displayed by a leader over time (Mathema, 2006). The researchers found that different leadership styles to be adopted depending on the situation and circumstances. It is also noted that the leadership styles are directly connected with their behavior. Mathema (2006) claims that a study of leadership styles, therefore, deals mainly with how the leader carries out their leadership functions or roles, use of authority and power, and approach to decision making (p. 56). This academic research works try to dig out whether the leadership styles of school principals vary with their educational level, job experience, and age or not. Are there any differences between male leadership and female leadership styles? Is the issue a muchdebated question? Eagly and Karau (2001) claimed, though there is a general agreement that women face more barriers to becoming leaders than men do, especially leader's roles are male-dominated. Many research articles and publications focus that the leadership style of women in the organizational setting is much more democratic than men. These studies have compared the leadership styles of males 
and females. Most of these studies have focused on a task and interpersonal style, and smaller numbers have examined autocratic style versus democratic and laissez-faire styles.

According to Eagly and Karau (2001), the extent that gender roles spill over to influence leadership behavior in organizational settings, the behavior of female leaders than that of male leaders may be more interpersonally oriented, democratic and transformational. In contrast, the behavior of the male leader, compared with that of female leaders, may be more tasks oriented and autocratic. In addition, the greater incongruence of the female than male gender role with typical leading roles may make it more difficult for women than men to manifest the more agented leadership styles (p. 13). The differences in leadership styles of leaders are based on the assumption that the leaders make a source of their power, authority, and human nature. Tannenbaum and Schmidt (2017) have also suggested the range of leader's behavior from extreme authoritarian to extreme democratic. There are different scholars in social sciences and management to claim varieties of leadership styles. Bogardus (1918) has suggested four types of leadership styles: The autocratic type who rises to office in a powerful organization, the democratic type which represents the interests of a group, the executive type who is goal granted leadership because he can get things done, and the reflective intellectual type who may find it difficult to recruit large followers.

Similarly, Levine (1949, as cited in Bass, 1990) has proposed four types of leaders. They are: The charismatic leader helps the groups rally around a common aim but tends to become dogmatically rigid, the organizational leader highlights and tends to drive people to effective action, the intellectual leader usually lacks skill in attracting people, and the informal leader tends to adopt his style of performance to group needs. There are different scholars they have their diverse perception of leadership styles.

Mathema (2006) has suggested that recent theorists have been primarily concerned with two major leadership styles; authoritarians and democratic. Both styles have been given new names. The authoritarian style is named as "task-oriented" or "structured" while the democratic is called "personal oriented" considerate (p. 59). Among the high leadership styles and approaches, Good worth (1988, as cited in Mathema, 2006) has stated that various leadership styles can be identified within each of the following management techniques. Each technique has its own set of good and not-so-good characteristics, and each uses leadership differently. Mathema (2006) has suggested that the lower studies identified the authoritarian, democratic, and laissez-faire leadership styles. These three leadership styles of higher secondary school principals have been taken as tools for this research issue based upon the assumption that principals' leadership styles can be judged by their managerial activities performed within schools' premises.

\section{Historical Background on Education System in Nepal}

According to Sebaly (1998, as cited in Anderson \& Lindkvist, 2000), rights to education for every citizen were adopted in Nepal in 1995. Before that, there was no right to education for all the people of Nepal because the autocratic constitution of Rana's period had no provision for education to anyone except for the royal family members and high ruling classes. The rulers fear that if people and lower cast people got free education, they would critically approach the system and get dissatisfied. Therefore, the people should be kept ignored, which was better (Estrad,1998 as cited in Anderson \& Lindkvist , 2000). At that time, the educational policy and system were not legalized and centralized. After 1971, the Government of Nepal first attempted to look at education as an "investment in human resource development (Sebaly, 1998 as cited in Anderson \& Lindkvist , 2000). After establishing democracy in Nepal, public debates were begun about rights to education for the people. After the 
world conference on education held in Jomtien (Thailand) in 1990, Nepal decided to endorse the Declaration and was agreed to "Education for All" (Anderson \& Lindkvist , 2000). Education in Nepal is structured as school education and higher education. School education includes pre-primary (nursery to upper KG), primary (grade 1-5), lower secondary (grades 6-8), secondary (grades 9-10), and higher secondary level (grades 11-12). Higher education consists of bachelor's degree, masters, and PhD. The duration of bachelor level may be three years to five years, depending upon the stream and subjects. The duration of master's degree is genuinely two years. Table 1 presents the national education structure in Nepal.

Table1

National Education Structure

\begin{tabular}{lll}
\hline Grade & Level & Normal Age \\
\hline 1 & Primary Education & 6 \\
2 & & 7 \\
3 & & 8 \\
4 & & 9 \\
5 & Lower Secondary Education & 10 \\
6 & & 11 \\
7 & Secondary Education & 12 \\
8 & & 13 \\
9 & Higher Secondary Education & 14 \\
10 & & 15 \\
11 & Higher Education (University) & 16 \\
12 & & 17 \\
13 & & 18 \\
14 & & 19 \\
15 & & 20 \\
16 & & 21 \\
$17+$ & & $22+$ \\
\hline Adopted from Ministry of Education, Keshar Mahal, Kathmandu, $2^{\text {nd }}(1996, p .3)$ (skar \& Cederroth, 1997 as cited in Anderson and Lindkvist 2000)
\end{tabular}

Legally there are two types of schools in the country: community and institutional. Community schools receive regular government grants, whereas institutional schools are funded by their own or other non-governmental sources. Institutional schools are organized either as a non-profit front or as a company. However, schools are mainly of two types: public (community) and Private (institutional).

\section{Higher Secondary Education System in Nepal}

Higher Secondary Education Board (HSEB), a higher secondary school certificate awarding body, was established in 2049 BS under higher secondary act 2046 BS. In the beginning year, 13 higher secondary schools were affiliated under HSEB all over the country. Still, today, there are more than 3500 higher secondary schools in Nepal where more than 800,000 students are studying in grades XI and XII. The objectives of higher secondary education are to manage Nepal's education system comparable to the education system of the other countries in the world and assure the quality of the higher secondary education system. The organizational structure of HSEB includes: a) Administrative department, Curriculum department, b) Planning, monitoring and evaluation department, c) Accreditation department, and d) Department of exam controller. Education minister is the chairman of the higher secondary education assembly. All higher secondary schools of the country are run under the control of the higher secondary education board. The principals in the higher secondary schools are important people who have executive rights and responsibilities.

There are very few research works undertaken in the area of schools' leadership in Nepal. However, in this research, an attempt has been made to review some of the studies and their findings directly or indirectly relevant to the present topic. Timalsina (2008) has researched the topic "school effectiveness criteria with reference to the public and private schools in Nepal." The major findings responding to 
the principals are as follows: Dedicated leadership was respected as one of Nepal's major factors of school effectiveness. Conflict among the teachers and management team and inactive school principals were respected as a major impending factor of school effectiveness. Principals of private schools were found to be more active than public schools. Positive thinking and strong leadership of head teachers' involvement in decision-making were reported as essential factors for school effectiveness by school management committee members. The status of private schools was found to be better than public schools in Nepal. The commitment of private schools to valuing the importance of school effectiveness criteria and their implementation was observed to be higher than that of public school.

Similarly, Sharma (2009) investigated school management in Nepal. The major findings regarding school leadership pointed out by this study are as follows: Schools lack systematic planning processes and do not reflect stakeholders' participation in school planning. Schools run on a ritual basis and rarely implements organizing practices. Headteachers have weak power and do not have the appropriate qualification to develop school-level leadership. Schools need more authorities and a transparent system of monitoring with reward and punishment.

Singh (2016) examined leadership practices of principals and found that all the principals had to deal with political interference, less support from government policies, poor administrative support from the higher authorities, a lack of financial and other resources, and severe at times and increased in competition from mushrooming schools as their chief challenges. The conclusion made by Singh is also supported by Mathema (2006). He claims that teachers' morale in most public schools results from inadequate resources, weak leadership, lack of professional support, and political interference.

I realized that young Principals were more interactive with the teachers and staff than old principals during my school visit. I also found that schools having female principals were mostly present at the station compared to male principals. The schools with known and old principals were rarely present in their room and what I met such personalities were very difficult for front desk officer. They demanded power distance. For these reasons I wish to know the determinant factors of the dominant leadership styles, whether it may be age, education level, experience period, or gender issue. Nowadays, employees of any school (teachers, staff) usually raise the issues of being isolated themselves from the management activities by founders. We have numerous examples that teacher unions, employees, and other organizations are debating their rights and responsibilities with the school management. Analyzing the overall scenarios, I have realized that decision-making, communication, and strategic planning are the key management components. Therefore, I try to quest to what extent the principal democratic, autocratic, or Laissez-faire with their employees for the managerial activities.

The leadership studies have focused on different types of leadership styles in different sectors. In the present study, the main focus of analysis is to the extent of the prevalence of various leadership styles in Nepal's educational sectors. To meet the need of this study the objectives of the study is to examine the extent of prevalence of various leadership style of principals/directors in private higher secondary Schools of Nepal and their different demographic characteristics. To address the objective of the study, the following research questions were designed:

- To what extent the leadership styles differ in relation to principals/directors' job experience in the field?

- To what extent the leadership styles differ in relation to principals/directors' education levels?

- To what extent the leadership styles differ in relation to principals/directors' age levels?

- Are there differences between the leadership style of male and female principals? 


\section{Method}

\section{Research Design}

The present research study was descriptive. Therefore, the study was qualitative. Though the research study was largely quantitative, both qualitative and quantitative approaches were applied to data collection and analysis. The quantitative approaches were applied to manage from close questionnaires to identify the variation of principals' leadership styles in relation to their demographic variables like age, sex, experience, and qualification. In contrast, qualitative approaches were mainly applied to manage interview data and secondary sources, which could not be done by the quantitative method.

\section{Sample Size}

The sample population of this research was higher secondary schools' principals and their teachers of Kathmandu Valley, which includes a higher secondary school of three districts Kathmandu, Lalitpur, and Bhaktapur. The sample area has covered more than $60 \%$ of the private higher secondary schools. There are 290 (two hundred and ninety) existing private higher secondary schools in Kathmandu Valley. Out of 290 principals, 225 male and 65 female were leading the schools. The target population was determined by Gupta (1992):

$n^{0}=z^{2} \frac{p q}{d^{2}}($ Gupta, 1992)

$=$ the confidence level (expected $95 \%)$

$\mathrm{p}$ and $\mathrm{q}$ are the proportion of female and male principals, respectively

$\mathrm{d}=$ permissible error is considered as $10 \%=0.10$

$\mathrm{n}^{0}=$ number of sample size

$\therefore n^{0}=\frac{(1.96)^{2} \times 0.288 \times 0.712}{(0.1)^{2}}$

$=78.77$

$=78$

From the calculated sample, the equivalent proportion of male principals (63) and female principals (15) and 163 teachers (two teachers from each school) were in the sample size. Table 2 presents the total number of respondents.

Table 2

Total Number of Respondents

\begin{tabular}{llll}
\hline Status & No. of H.S.S & No. of respondent & \% of respondent \\
\hline Male-principal & 63 & 63 & $26.58 \%$ \\
Female-principal & 15 & 15 & $7.59 \%$ \\
Teachers & 163 & 163 & $66.66 \%$ \\
Total & 241 & 241 & $100 \%$ \\
\hline
\end{tabular}

*Higher Secondary School

\section{Instruments}

The questionnaires were defined focusing on management functions to be performed by the principals. Each element of the questionnaires is related to major managerial functions like decision making, controlling, communication, participation isolation or involvement, motivation, job allocation, goal setting, performance appraisal, planning, etc. The same questionnaires were administered to principals and teachers to compare the perception of the both respondents to identify the leadership styles of principals. The leadership questionnaires concern the three dimensions of leadership styles. They are democratic leadership style (seven statements), autocratic leadership style (five statements), and laissez fair leadership style (five statements) with response categories ranging from "strongly disagree" 
to "strongly agree" in 1 to 5 quantitative rating scales. The statements of the related style are presented in Table 3.

Table 3

The Statements of the Questionnaire

\begin{tabular}{|c|c|c|}
\hline & $\begin{array}{l}\text { Statement number } \\
\text { in questionnaire }\end{array}$ & Statements in questionnaire \\
\hline \multirow{7}{*}{$\begin{array}{l}\text { Democratic style } \\
\text { statements in the } \\
\text { questionnaire }\end{array}$} & DL Q.1 & Teachers prepare job objectives and discuss with their principal for final approval. \\
\hline & DL Q.2 & Delegation of power to teachers in this school is strongly exist. \\
\hline & DL Q.3 & Teachers from different departments and levels sit together to solve the organizational problems. \\
\hline & DL Q.4 & $\begin{array}{l}\text { Participative decision making is encouraged to teachers in decision on adoption of new policies } \\
\text { and programs. }\end{array}$ \\
\hline & DL Q.5 & Teachers are encouraged to discuss about the organizational problems freely and frankly. \\
\hline & DL Q.6 & Communication moves freely, horizontally, vertically and laterally. \\
\hline & DL Q.7 & Teachers participate to determine school resources allocation and utilization in the school. \\
\hline \multirow{5}{*}{$\begin{array}{l}\text { Autocratic style } \\
\text { statements the in } \\
\text { questionnaire }\end{array}$} & AL Q.8 & Principal determines all the activities to be done by teachers. \\
\hline & AL Q.9 & Principal always makes decision himself/herself. \\
\hline & AL Q.10 & School management introduces the change without explaining the concept. \\
\hline & AL Q.11 & School management always threatens and pressurizes the teachers in their job. \\
\hline & AL Q.12 & $\begin{array}{l}\text { Instructions are imposed on the teachers with expect to the job performing procedures and } \\
\text { methods. }\end{array}$ \\
\hline \multirow{5}{*}{$\begin{array}{l}\text { Laissez-faire style } \\
\text { statements in the } \\
\text { questionnaire }\end{array}$} & LL Q.13 & The principal always tries to get teachers' ideas and opinions and make constructive decision. \\
\hline & LL Q.14 & Teachers are given freedom to set their goals. \\
\hline & LL Q.15 & Teachers have freedom to appraise their performance themselves. \\
\hline & LL Q.16 & Decentralization of power for making decision is large. \\
\hline & LL Q.17 & Information of all types are accessible at any time. \\
\hline
\end{tabular}

Note. DL Q = Democratic Leadership Questionnaire, AL Q = Autocratic Leadership Questionnaire, LL Q = Laissez-faire Leadership Questionnaire

The percentage distribution of respondents' male principals, female principals and teachers is $26.58 \%, 7.59 \%$, and $66.66 \%$, respectively. The questionnaires were administered to the respondent and returned. Data collected by this survey were analyzed statically using the STATA program to calculate mean, standard deviation, and coefficient of variation. The distribution of respondent principals and teachers regarding their age, experience, and academic qualifications was separately calculated.

\section{Validity and Reliability}

In order to assure validity, the tools and techniques designed for the study were handed to the supervisors and other senior academicians for analysis and provision of feedback. Then, they were revised according to their guidance and suggestions. Besides, the literature review also helped me to design the study. According to Joppe (2000), validity determines whether the research truly measures what it was intended to measures or how truthful the research results are. Similarly, reliability refers to the level of dependability of the items in the research instrument and the consistency of the research instruments in tapping information from more than one respondent (Nsubuga, 2008). For this research, the reliability test was performed by a pilot survey on a small population (10\% of the sample size). The results of the pilot study provided authenticity to proceed with data collection.

\section{Analysis and Results}

The age-wise distribution of principals and teachers was 21 - 30 years, 31-40, 41-50, and 51+ years. Similarly, experience-wise made the difference of 10 years, i.e., 1-10 years, 10-2, and 20+ years of experience. The minimum requirement for higher secondary school principals or teachers, at least, is to pass master's degree. The descriptive, statistics and cross-sectional tabulation analysis technique were applied to assess the leadership styles of higher secondary school principals. Using stata 
programming, standard deviation and coefficient variation were calculated to interpret the results. The element-wise analysis was performed in relation to each leadership style to know the leadership styles of principals in their specific management functions.

Table 4 shows that male principals perceived the greatest extent of democratic leadership style. The mean value of male principals is 3.28 , which is greater than mid-value 3 , and the lowest mean is 2.62 obtained for female teachers. Male and female principals and male teachers perceived the prevalence of democratic leadership style since the mean values are greater than mid-value 3 . Female teachers perceived that the prevalence of leadership styles of principals is not democratic. The greater variation in the response (.29) has been found in male teachers, whereas female principal variation is the lowest (.19).

Table 4

Private School's Principal by Gender

\begin{tabular}{lcccc}
\hline Gender status & Number & $M$ & $S D^{*}$ & $C V^{*}$ \\
\hline M. principal & 63 & 3.28 & 0.86 & 0.26 \\
F. principal & 15 & 3.13 & 0.60 & 0.19 \\
M. teacher & 147 & 3.05 & 0.90 & 0.29 \\
F. teacher & 16 & 2.62 & 0.67 & 0.25 \\
Total & 241 & 3.09 & 0.87 & 0.28 \\
\hline
\end{tabular}

Note. ${ }^{*} \mathrm{CV}=$ Coefficient of Variation

Table 5 presents the age-wise data of principals. The respondents have been made four age groups: 21 to 30 years old, 31 to 40, 41 to 50 and more than 50 years old. The data showed that all age groups perceived the prevalence of almost equal democratic leadership style except age group 21 to 30 years. The age group 21 to 30 years old has scored the lowest mean 2.77 which is less than the mid-value. On the other hand, the mean scores of all age groups of principals except 21-30 are greater than the mid-value. The greatest variations .42 have been found in the principals of the age group 21 to 30 whereas the lowest variation is .20 in the respondents' (principals') responses of age group above 51 years old.

Table 5

Private School's Principal by Age Groups

\begin{tabular}{lcccc}
\hline Principals age group & Number & $M$ & $S D$ & $C V^{*}$ \\
\hline 21 to 30 years & 3 & 2.77 & 1.17 & 0.42 \\
31 to 40 years & 22 & 3.31 & 0.93 & 0.28 \\
41 to 50 years & 31 & 3.19 & 0.80 & 0.25 \\
51 years above & 22 & 3.33 & 0.69 & 0.20 \\
Total & 78 & 3.25 & 0.82 & 0.25 \\
\hline
\end{tabular}

Note. ${ }^{*} \mathrm{CV}=$ Coefficient of Variation

Table 6 shows the democratic leadership style of principal perceived by different age groups of teachers. The greatest variation is .30, and the lowest is .25. The age groups 21 to 30 years and 31 to 40 years old teachers responded that their principals are democratic leaders. The mean value of 41 to 50 years and above 51 years old teachers are 2.93 and 2.83 , respectively, below the mid-value 3 . So, these age groups' teachers did not perceive the principals' prevalence of democratic leadership style.

Table 6

Democratic Leadership Style

\begin{tabular}{lllll}
\hline \multicolumn{1}{c}{ Principals' age group } & Number & $M$ & $S D$ & $C V^{*}$ \\
\hline 21 to 30 years & 51 & 3.06 & 0.93 & 0.30 \\
31 to 40 years & 85 & 3.01 & 0.89 & 0.29 \\
41 to 50 years & 25 & 2.93 & 0.86 & 0.28 \\
51 years above & 2 & 2.83 & 0.70 & 0.25 \\
Total & 163 & 3.01 & 0.89 & 0.29 \\
\hline Note. $*$ CV Coefficient of Variation & & & &
\end{tabular}

Note. ${ }^{*} \mathrm{CV}=$ Coefficient of Variation 
Table 7 shows the academic qualification of principals did not drastically affect the leadership styles of principals. The mean value of principals having master's degree, MPhil, and $\mathrm{PhD}$ degree qualification followed democratic leadership style. The principals with MPhil degree qualification scored 3.77 mean value which is the highest mean score. So, principals themselves perceived the prevalence of democratic leadership style. The variation is .24 that lies in master's degree holders, and the highest variation lies in $\mathrm{PhD}$ holders, which is .28.

Table 7

Private School's Principals by Academic Status

\begin{tabular}{lcccc}
\hline Academic Status & Number & $M$ & $S D$ & $C V^{*}$ \\
\hline Master degree & 61 & 3.19 & 0.78 & 0.24 \\
MPhil & 9 & 3.77 & 0.92 & 0.24 \\
PhD & 8 & 3.08 & 0.86 & 0.28 \\
Total & 78 & 3.25 & 0.82 & 0.25 \\
\hline
\end{tabular}

Note. ${ }^{*} \mathrm{CV}=$ Coefficient of Variation

In Table 8, statement No. 5 presents "organizational problems" and statement No. 4 represents "decision making". The highest mean scores recorded mean score of 4.33 for statement No. 5 and a score of 4.26 for statements No. 3 and 4. The remaining statements 1, 2, 6, and 7 were rated more than mid-value. Hence, the presented data informed that female principals follow democratic leadership styles in their administrative functions. They become more democratic with respect to managerial functions like "decision making" and "discussions with organizational problems."

Table 8

Statement Analysis

\begin{tabular}{lcccc}
\hline Statement No. & Number & $M$ & $S D$ & $C V^{*}$ \\
\hline DL Q.1 & 15 & 3.66 & 0.72 & 0.19 \\
DL Q.2 & 15 & 3.86 & 0.63 & 0.16 \\
DL Q.3 & 15 & 4.26 & 0.70 & 0.14 \\
DL Q.4 & 15 & 4.26 & 0.48 & 0.16 \\
DL Q.5 & 15 & 4.33 & 0.59 & 0.11 \\
DL Q.6 & 15 & 3.73 & 0.83 & 0.15 \\
DL Q.7 & 15 & 4.13 & & 0.20 \\
\hline
\end{tabular}

Note. $* \mathrm{CV}=$ Coefficient of Variation

Table 9 presents the respondents' experienced group of 21 years and above who have scored the highest mean for statement No. 5, which is "teachers are encouraged to discuss the organizational problems freely and frankly," and its mean score is 4.17. Similarly, they gave a 4.08 score for the statement of "decision making". The wise analysis of democratic leadership style considering total respondents in relation to their service experiences was conducted. All the experienced groups perceived the prevalence of democratic leadership styles for all statements like "Job objectives", "delegation of power", "participation in decision making", "communication", and "goal setting". The mean scores of all statements are greater than the mid-value. The data revealed that principals were more democratic in "discussions with organizational problems" and "decision making" and also showed that the existing leadership style of the higher secondary school in Nepal is dominantly democratic. 
Table 9

Respondents' Experience

\begin{tabular}{|c|c|c|c|c|c|c|c|c|c|c|c|c|}
\hline Statement No. & $1-10$ & & & $11-2$ & & & $21 \mathrm{~J}$ & s abov & & total & & \\
\hline & No. & $M$ & $S D$ & No. & $M$ & $S D$ & No & $M$ & $S D$ & No. & $M$ & $S D$ \\
\hline DL Q.1 & 142 & 3.62 & 0.83 & 76 & 3.44 & 0.83 & 23 & 3.60 & 1.30 & 241 & 3.56 & 0.88 \\
\hline DL Q.2 & 142 & 3.38 & 0.85 & 76 & 3.48 & 0.80 & 23 & 3.87 & 0.75 & 241 & 3.46 & 0.84 \\
\hline DL Q.3 & 142 & 3.69 & 0.90 & 76 & 3.59 & 0.86 & 23 & 3.75 & 0.82 & 241 & 3.68 & 0.88 \\
\hline DL Q.4 & 142 & 3.61 & 0.95 & 76 & 3.67 & 0.80 & 23 & 4.08 & 0.79 & 241 & 3.68 & 0.90 \\
\hline DL Q.5 & 142 & 3.60 & 0.96 & 76 & 3.75 & 0.81 & 23 & 4.17 & 0.83 & 241 & 3.73 & 0.91 \\
\hline DL Q.6 & 142 & 3.45 & 0.84 & 76 & 3.73 & 0.77 & 23 & 4.04 & 0.87 & 241 & 3.60 & 0.84 \\
\hline DL Q.7 & 142 & 3.28 & 0.88 & 76 & 3.48 & 0.75 & 23 & 3.43 & 0.89 & 241 & 3.36 & 0.85 \\
\hline
\end{tabular}

\section{Summary Major Findings}

Democratic Leadership Styles of Principal

- Statistically, the gender-wise analysis showed that the mean values of male and female principals and male teachers are 3.28,3.13, and 3.05, respectively, which are greater than three. On the other hand, female principals got a low score of 2.65 , i.e., less than 3 .

- The results showed that all respondents between 21 to 30 years scored greater than mid- value 3. The greatest variation .44 has been found in the principals between the age group 21-30 years. Similarly, the age groups 21-30 years and 31-40 years old teachers had mean values greater than 3 and 41-50 years and above 51 years had the mean score less than three.

- Principals with master's degree qualification, MPhill, and PhD degree holders scored mean values greater than 3 . The greatest variation lies in master degree holder principals. Only the teacher with master's degree qualifications gave lower scores (i.e., 2.77 mean less than 3) for the democratic leadership styles of their principals.

- Principals with more than 20 years and less than 10 years of experience gave high mean scores. The teachers with less than 10 years of experience gave high scores, but 11 years and more experienced teachers did not perceive democratic leaders.

\section{Autocratic Leadership Styles of Principals}

- Principals, both male and female with different age groups, having other work experience periods and academic degrees, did not perceive themselves as autocratic leadership styles. The mean scores of all the cases were found to be less than mid-value 3 .

- The teachers of all age groups having other work experiences and qualifications (except $\mathrm{PhD}$ ) did not perceive principals as autocratic educational leaders. However, only $\mathrm{PhD}$ holder teachers gave a high mean score which is greater than mid-value.

Laissez-faire Leadership Styles

- Male and female principals of all age groups having other academic qualifications and work experiences did not perceive themselves as Laissez-faire since the mean scores were less than mid-value 3. Similarly, teachers of all age groups with other experience and academic qualifications (except $\mathrm{PhD}$ ) did not perceive Laissez-faire leadership styles of principals. Only $\mathrm{PhD}$ holder teachers gave a mean score of 4 and pointed to the Laissez-faire leadership style.

\section{Element-wise Analysis of Leadership Styles of Principals.}

- Both male and female principals and teachers accepted the democratic leadership styles and all the seven management functions. Similarly, they did not support autocratic leadership styles in all the five functions of management. But teachers supported principals with Laissez-faire 
leadership in some management functions, for instance, freedom of communication to set a goal and participation to make constructive decisions.

- The qualitative research work (interviews) was undertaken with various respondents, and they have almost supported the democratic leadership styles. A district education officer reflected this perception regarding the leadership style of principals.

"The principals must have clear vision in order to bring the cordial relationship among the staff, parents, other stakeholders and community for the improvement of school performance and to be recognized as an effective school leader." The response of a mathematics faculty member on the same question was:

"Because of the democratic type of leadership exhibited by the principal, staffs are always free to give suggestions and comments for the betterment of school performance." The perception of an English lady teacher about her principal was similar to a mathematics faculty member. She revealed:

"Our principal is very friendly. We do not have any hesitation to put our problems in front of him. He makes the cordial relationship among us. He treats equally each staff and teacher. We are invited to participate in the meeting. So, we are proud of our principal's managerial skill and positive attitude." The above connections with all the respondents reflect the democratic leadership styles of principals.

\section{Discussion}

The statistical findings of quantitative data showed that almost all principals of private higher secondary schools in Nepal use democratic leadership styles dominantly. All principals have perceived themselves as good democratic education leaders. The principals value the good relation with teachers, the feeling of the teachers, and their role and responsibilities, which provide a good atmosphere for the teachers. So, the key leadership competency of the school principal is to know how to scan the internal and external environment of the institution properly. It is also supported by research work undertaken by Rajbhandari (2002) about the school leaderships of Nepalese education, which states that leadership style can be defined according to the institutions' environment. Therefore, it is the situation that demands the adaptation of leadership style in an organization. Conclusively, it is noted that Nepal's private schools' leadership is dominantly democratic in relation to the management functions performed by the principals. In addition, they have also practiced autocratic leadership style and laissez-faire leadership style to some extent. It is also found that the respondent (teachers) having a high degree (MPhil and $\mathrm{PhD}$ ), high age (51 years above), and more job experienced (20 years and above) did not perceive the democratic leadership style of their principals. It was also noted that the majority of teachers have agreed that their principals' leadership style is autocratic in few management functions like job performance and job allocation. Similarly, they accepted the laissez-faire leadership style of the principal in relation to communication, decision-making, and goal setting.

In brief, the major findings of this study have indicated that the leadership style of private higher secondary schools' principals in Nepal is democratic. There are several reasons behind the democratic education management practices in Nepal. The country's autocratic political system has been changed into a complete democratic paradigm (Bush, 2010). Since school districts are part of society, there is a direct effect of national politics in the private education system. Bush (2010) says "democracy expects of its education system and its leadership growth of the nation to be equipped to assume responsibilities in political setting." Therefore, the principals virtually undertake democratic leadership and practice democratic style in their higher secondary school in the recent year to cope with the new 
change in Nepal.

\section{Conclusions}

The prime objective of this research study was to identify the existing leadership style of private higher secondary school principals in which the three dimensions of leadership styles were considered. They were democratic, autocratic and laissez-faire leadership styles. It was also believed that these three scales of leadership styles may prevail in the private higher secondary schools in Nepal. Questionnaires were designed which included the major functions of school management to examine the dimension of leadership styles. The questionnaires were provided to the principals themselves and their teachers to collect the data. In the previous sectors, the collected data were presented and analyzed for the discussion. The main conclusions made by the findings and discussions of this study were summarized as:

- Leadership style of private higher secondary schools' principals is dominantly democratic, and Laissez-faire and autocratic leadership style are rarely present.

- Perception variations are noted in gender issues of leadership styles.

- Slight percentage variations are noted between more experienced and less experienced, younger and older teachers and teachers with different levels of academic qualification.

- Demographic characteristics such as level of education, age, and work experience have been seen as small determinant factors to evaluate principals' leadership styles.

- Principals adopt different leadership styles in different managerial functions.

The following implications for leadership practices have been presented from the research findings and conclusions. The private school leadership should scan the internal and external environment while practicing the educational leadership responsibility. The internal environment includes teachers, staff, and students. The external environment includes society, parents, various social organizations, education-related offices, and educationalists. Principals should be informed about the different approaches to educational leadership practices because a single leadership style may not always fit to achieve the objectives of schools. Principals should be provided professional development leadership training programs and education leadership style training programs which help them to gain a better knowledge of how and when to apply the appropriate leadership style in the school. Finally, principals of private schools should be aware of the educational leadership of the 21 st century and follow the norms and values of a universal democratic leadership style.

The present study focused only on the three different dimensions of leadership styles. The three patterns of leadership styles are not enough for the current education era. Therefore, for future research, it is advised to identify the distinct patterns of leadership styles. Furthermore, the present study is limited to the principals that are employed for the private higher secondary school levels (Grade XI and XII). It would be more prudent to study the leadership styles of both private and public secondary schools along with technical secondary schools. Therefore, it is advised for future researchers to find out the leadership styles of principals of all kinds of secondary schools. This study only examined the perceptions of teachers and principals themselves. It would be more beneficial to conduct further research that examines other stakeholders' perceptions, such as parents, students, community members, staff, and other related people. Such research work could provide valuable data in comparing how different groups view the principals' leadership styles. This study presented the knowledge of existing leadership practices of principals in private higher secondary schools. Further research is needed to identify whether specific leadership styles of principal impacts on school performance. 


\section{References}

Anderson, J., \& Lindkvist, J. (2000). Education in Nepal. Retrieved from http://www.divaportal.org/smash/get/diva2:22833/FULLTEXT01.pdf

Bass, B. M. (1990). Bass \& Stogdill's handbook of leadership: Theory, research, and managerial application (3rd ed.). New York: Free Press.

Bogardus, E. S. (1918). Essential of social psychology. Los Angles: University of Southern, California Press.

Bush, K. (2010). School leadership and political impact on nation (2nd ed.). London: Routledge.

Eagly, A. H., \& Karau, S. J. (2001). Role conrguity theory of prejudice toward female leaders. Psychological Review, 109(3), 573598.

Gupta, S. C. (1992). Fundamentals of statistics (5th ed.). New Delhi: Himalayan Publishing House.

Joppe, M. (2000). The research process. Retrieved from http://www.peoplelearnhomestead.com.

Mathema, S. B. (2006). Cross sectional leadership style and Job satisfaction in business enterprises in Nepal (Unpublished doctoral dissertation). Faculty of Management, Tribhuwan University, Kathmandu, Nepal.

Nsubuga, Y. (2008). Analysis of leadership styles and school performance of secondary schools in Uganda (Unpublished doctoral dissertation). Nelson Mandela Metropolitan University, Faculty of Education, Nzare Aare, New Zealand.

Pont, B., Nushe, D., \& Moorman, H. (2008). Improving school leadership (Policy and Practice volume 1). Retrieved from https://search.oecd.org/education/school/40545479.pdf

Rajbhandari, M. D. (2002). Dominant leadership style in school (Unpublished MPhil thesis). School of Education, Kathmandu University, Kathmandu, Nepal.

Robbins, R. S., \& Judge, A. T. (2007). Organizational behaviour (12th ed.). New Delhi: Practice Hall of India.

Sapkota, S. K. (2008). School leadership in public school in Nepal (Unpublished master's thesis). School of Education, Kathmandu University, Kathmandu Nepal.

Sharma, C. L. (2009). A study on the causes of education migration in Nepal (Unpublished MPhil thesis). Kathmandu University, Kathmandu Nepal.

Singh, S. (2016). Leadership practices of selected public secondary schools in Kathmandu, Nepal (Unpublished master's thesis). The University of Western Ontario, Canada.

Sungtong, E. (2007). Leadership challenges to public secondary school principals in the era of education reform and culture unrest in boarder provenance of Southern Thailand (Unpublished doctoral dissertation). Faculty of the Graduate School at the University of Missouri Columbia, USA.

Tannenbaum, R., \& Schmidt, W. H. (2017). How to choose a leadership pattern. In A. Hooper (Ed.), Leadership perspectives (pp. 7584). New York, NY: Routledge. doi:10.4324/9780429494000

Timalsina, T. P. (2008). Criteria with reference to the public and private school in Nepal. (Unpublished doctoral dissertation). School of Education, Kathmandu University, Kathmandu Nepal.

\section{Acknowledgments}

Not applicable.

\section{Disclosure Statement}

No potential conflict of interest was reported by the authors.

\section{Funding Acknowledgments}

Not applicable.

\section{Open Access}

The International Journal of Organizational Leadership publishes open access articles under the terms of the Creative Commons Attribution (CC BY) License, which permits use, distribution, and reproduction in any medium, provided the original work is properly cited. 